\title{
THE COMPARISON OF PISA EDUCATIONAL RESULTS WITH GROSS DOMESTIC PRODUCT IN MEMBER STATES OF EUROPEAN UNION
}

\author{
Peter Plavčan $^{1}$
}

\begin{abstract}
The Programme for International Student Assessment (PISA) - an OECD international survey project, has become the base for an international comparison of students' results. This publication is oriented on the wide evaluation of basic statistical data in scientific, mathematical and reading literacy of students. We compare the main results of students in scientific, mathematical and reading literacy and the tendencies of GDP and expenditure to education from the GDP of the Member states of the European Union. PISA helps identify key problems and create effective school policy for all stakeholders.

It seems evident that the above-average education expenditure percentage of the gross domestic product affects also the above-average values of the index of the sum of the scores obtained in the pupils' scientific, mathematical as well as reading literacy for the sum of the years 2006, 2009, 2012 and 2015 in the period under review. It seems Member States which spend a higher above-average education expenditure percentage of their gross domestic product have, on a long-term basis, aboveaverage and relatively stable results in the summary index but also individually - in the pupils' scientific, mathematical and reading literacy.

Political and professional decisions to increase education expenditure evidently positively affect the quality of education at schools in general, regardless of how the "economy is doing". Our results of the analysis support the assumption that even in the case of a state's restrictive budget, expenditure on education and creative activity in general should not be restricted.
\end{abstract}

UDC Classification: 338.2, DOI: 10.12955/cbup.v7.1422

Keywords: PISA, scientific literacy, mathematical literacy, reading literacy, education, gross domestic product, students

\section{Introduction}

The Programme for International Student Assessment (PISA) is an OECD international survey project aimed at finding out how 15-year-old pupils can creatively combine their knowledge from various subjects and areas to solve problems. Statistical indices have shown the scores obtained in the areas of scientific, mathematical and reading literacy by pupils of the EU Member States in international surveys during the entire period of the PISA project since 2000, but mainly during the reference period, i.e. from 2006 to 2015, allow for the performance of several analyses.

Within the analysis, we will use a cumulative total of the pupils' results in regard to their scientific, mathematical and reading literacy for the years 2006, 2009, 2012 and 2015. The cumulative total made in such way (summary index) provides for one figure for particular Member States including results of four surveys which to into regard three literacy types. It can be assumed that this statistical index allows for a comparison of the long-term development tendency in the pupils' results as an aggregate in the scientific, mathematical and reading literacy among the Member States of the European Union. It seems, there are some connotations between education and economic parameters (Hanushek, 2016).

\section{Summary Index of the Scientific, Mathematical and Reading Literacy}

When assessing the summary index of the pupils' scientific, mathematical and reading literacy for the reference period 2006 to 2015, we have come to the following conclusions:

1. Exactly half of the EU Member States, i.e. 14 Member States, are above the average (the average score: 5859) in the overview of the EU Member States - sum of the scores obtained in the pupils' scientific, mathematical and reading literacy summed together for the years 2006, 2009, 2012 and 2015. The Member State with the highest score in the ranking is Finland (score: 6445), followed by Estonia (6239), the Netherlands (6199), Germany (6115), Belgium (6096), Ireland (6091), Poland (6077), Slovenia (6037), the United Kingdom (6011), Denmark (6007), Austria (5990), France (5956), the Czech Republic (5949) and Sweden (5931). This group of Member States includes states with a significant growth of their scores in particular surveys by the literacy types, with a balanced tendency of the scores obtained, but also Member States with a significant decrease in the scores obtained by the pupils in the literacy types, however, with their results still being above-average in general. Finland has one of the biggest decreases in the scores in all literacy types in the reference period 2006 to 2015 from among all Member States, but has for a stable position at the absolute forefront of the Member States ranking in the PISA international surveys.

\footnotetext{
${ }^{1}$ Vysoká škola Danubius, Sládkovičovo, Slovakia, peter.plavcan@vsdanubius.sk
} 
In some of the Member States in this group of the overview with an above-average value of the summary index, it is worthy of consideration to look for reasons for the decreased scores in particular in the surveys of the scientific, mathematical and reading literacy and search for a way of stopping such decrease, whether by changing the curriculum and teaching methods, by changing the school climate, changing the management at all levels, or looking for other reasons for the deteriorating, yet still above-average results of the pupils in those Member States. However, the EU Member States in this group with above-average results of the summary index have challenges for the entire period in question in the area of school policy different from the Member States that are below the average value of the summary index.

2. The following Member States are below the average of the summary index (score: 5859) sum of the scores achieved by the pupils in the scientific, mathematical and reading literacy for the summed together with for the years 2006, 2009, 2012 and 2015 in the reference period: Latvia (score: 5857), Hungary (5847), Portugal (5836), Spain (5824), Luxemburg (5819), Italy (5789), Lithuania (5757), Croatia (5732), Slovakia (5715), Greece (5584), Malta (5564), Cyprus (5276), Bulgaria (5185) and Romania (5143). This group of the Member States with the below-average value of the summary index includes the Member States with a favourable growing tendency of scores obtained. The Member States with the most significant growth from among all Member States of the European Union include Romania and Bulgaria, which are at the same time in the last two places in the ranking from among all Member States of the European Union.

\section{Summary Index and Gross Domestic Product}

We have selected the macroeconomic index - GDP, often used for the benchmarking or formulation of development tendencies in the state's economy, for the purposes of finding potential relations between this macroeconomic index and the results of the pupils of the Member States of the European Union in the summary index. The gross domestic product increment percentage index integrates various tendencies of development in economic sectors and industries and its expression in a single value has informative value and high demonstrativeness. The information stated with respect to the gross domestic product increment is for 2017, Romania, Bulgaria, Cyprus, Hungary and Croatia - for 2016: Finland 2.63, Estonia 2.24, the Netherlands 4.65, Germany 3.05, Belgium 5.0, Ireland 2.67, Poland 2.32, Slovenia 2.66, the United Kingdom 1.79, Denmark 4.76, Austria 1.73, France 7.81, the Czech Republic 3.99, Sweden 3.3, Latvia 3.1, Hungary 2.0, Portugal 2.51, Spain 2.32, Luxembourg 1.57, Italy 4.55, Lithuania 4.6, Croatia 2.9, Slovakia 3.83, Greece 1.3, Malta 3.4, Cyprus 2.8, Bulgaria 3.4, Romania 4.8 (OECD Data, 2017).

The following graphical presentation shows the relations of two statistical indices, i.e. of the "summary index" and the "gross domestic product increment percentage" index in the EU states. A Member State's position in the graphical presentation (it is designated by an international abbreviation of the Member State) is shown by an intersection point of the scores obtained in the summary index of the Member State and gross domestic product increment percentage of the Member State expressed as a percentage.

The horizontal line in the graphical presentation shows an approximate average value of the summary index. The Member States below that line are below the average value of the summary index and the Member States above that horizontal line are above the average value of the index.

The vertical line in the graphical presentation shows an approximate average value of the gross domestic product increment percentage for all Member States as an average for all Member States of the European Union. The gross domestic product increment percentage of the Member States that are to the left of that vertical line are below the average value of the gross domestic product increment percentage for all Member States and the Member States to the right of that vertical line are above the average of this index.

Several findings result from the displayed positions of particular Member States. Member States with the gross domestic product increment above the average as well as below the average for all Member States shown by the vertical line are above the average of the summary index. It is interesting that the states with a value of the index of the score achieved by the pupils in the summary index high in the long term are in the left upper quadrant ; specifically, Finland and Estonia. 


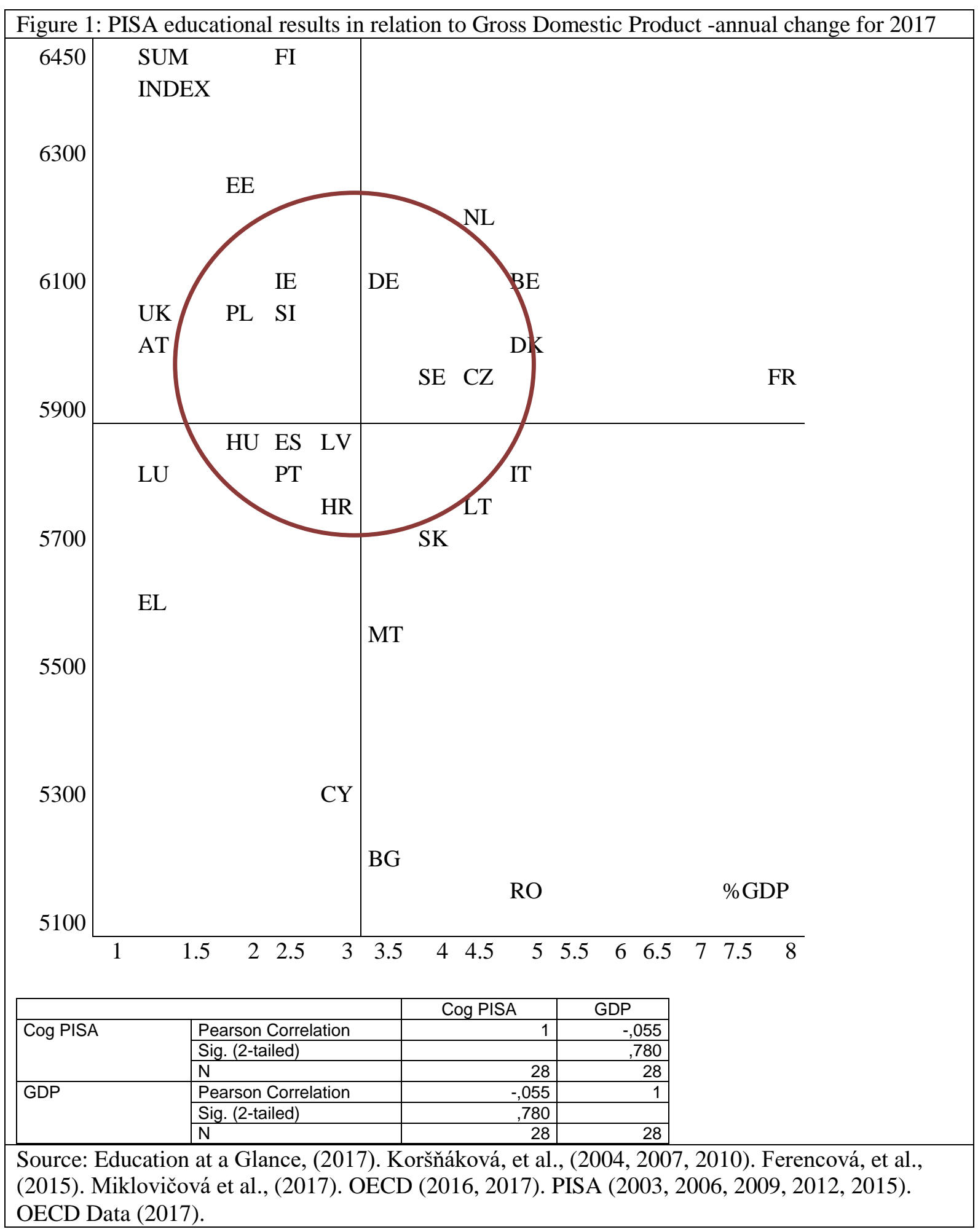

It means that it can be stated particularly when assessing those states that the level of the of the gross domestic product increment does not affect the pupils' educational results at those schools on a yearover-year basis in regard to the subjects and selected contents of the subjects (curriculum) within the framework of the PISA international survey. This fact is particularly interesting in the case of Estonia, which has a leading position in statistical surveys, but its results between particular international surveys are continuously improved despite the below-average value of the gross domestic product increment index. This indicates that the level of the gross domestic product increment in individual Member States (the "economy growth") does not have to be decisive in affecting the quality of education in our analysis of the PISA. 
An interesting group in this graphical presentation is in the lower part of the right lower quadrant, i.e. Bulgaria and Romania. These two Member States are below the average of the summary index value (the horizontal line in the graph) and are above the average value of the gross domestic product increment shown by the vertical line. Despite the above-average value of the gross domestic product increment, those Member States are below the average value of the summary index, but belong among the Member States with the highest increments of scores in international surveys also individually, in scientific, mathematical and reading literacy. Italy, Lithuania, Slovakia and Malta are also in this right lower quadrant. From among those Member States, only Slovakia records an absolute as well as relative decrease in the scores individually in scientific $(-3.5 \%)$, mathematical $(-3.5 \%)$ and reading literacy $(-2.8 \%)$; this decrease belongs among the highest ones in particular literacy types for all Member States of the European Union. Malta has started conducting the international survey later than other states; this is why it is impossible to assess it due to the lack of statistical indices.

\section{Summary Index and Expenditure on Education from Gross Domestic Product}

The graph stated below presents relations of two statistical indices, specifically, of the "summary index" and "percentage of expenditures on education of gross domestic product" index of the EU states. The statistical data on the gross domestic product increment percentage are stated from the OECD statics from 2017. Taking into regard the availability and, above all, completeness of the statistical data, it concerns the public expenditure for three educational degrees for 2014: Denmark 6.3, Finland 5.6? Belgium 5.6, Sweden 5,2, Portugal 4.9, the United Kingdom 4.8, France 4.8, Estonia 4.7, Austria 4.7, the Netherlands 4.5, Ireland 4.4, Latvia 4.4, Poland 4.3, Slovenia 4.1, Lithuania 3.8, Germany 3.7, Italy 3.6, Spain 3.5, Luxembourg 3.5, the Czech Republic 3.4, Hungary 3.4, Slovakia 3.4, Croatia 3.4 (qualified estimate), Malta 3.4 (q. e.), Greece 3.4 (q. e.), Bulgaria 3.4 (q. e.), Romania 3.4 (q. e.), Cyprus 3.4 (q. e.) (Education at a Glance, 2017).

The position of the EU Member State is shown in the graph by a state's abbreviation and expresses an intersection point of the obtained sum of the scores obtained in the summary index of the EU Member State and the index of the education expenditure percentage of the gross domestic product of the Member State.

The horizontal line in the graph indicates an approximate mean value of the summary index. Member States below this line are below the average value in the summary index and Member States above the horizontal line are above the average value in the index.

The vertical line the graph indicates an approximate average value of the education expenditure percentage of the gross domestic product for all Member States as an average for all EU Member States. Member States to the left of that vertical line have the value of the index of the expenditure percentage of the gross domestic product below the average value for all Member States and Member States to the right of that vertical line are above the average value in this index.

In the overview of the EU Member States, exactly half of the Member States, i.e. 14 Member States, are above the average (average score: 5859) of the summary index expressed by the horizontal line. The first place in the ranking with the highest score belongs to Finland (score: 6445), followed by Estonia (6239), the Netherlands (6199), Germany (6115), Belgium (6096), Ireland (6091), Poland (6077), Slovenia (6037), the United Kingdom (6011), Denmark (6007), Austria (5990), France (5956), the Czech Republic (5949) and Sweden (5931). Most of the Member States have a position shown in the graph in the right upper quadrant, which means, that in addition to the above-average value of the summary index, we also register an above-average value of the index of the education expenditure percentage of the gross domestic product in the case of those Member States. From this group of the EU Member States, only Germany and the Czech Republic have a below-average value in the index of the education expenditure percentage of the gross domestic product.

From among the EU Member States, the following Member States are below the average (average score: 5859) of the summary index expressed by the horizontal line: Latvia (score: 5857), Hungary (5847), Portugal (5836), Spain (5824), Luxembourg (5819), Italy (5789), Lithuania (5757), Croatia (5732), Slovakia (5715), Greece (5584), Malta (5564), Cyprus (5276), Bulgaria (5185) and Romania (5143). This group of the Member States with a below-average value of the summary index includes the Member States in the case of which a favourable growing tendency of the score obtained is registered. The Member States with the most significant growth from among all Member States 
include Romania and Bulgaria, which are at the same time in last places in the ranking from among all Member States of the European Union.

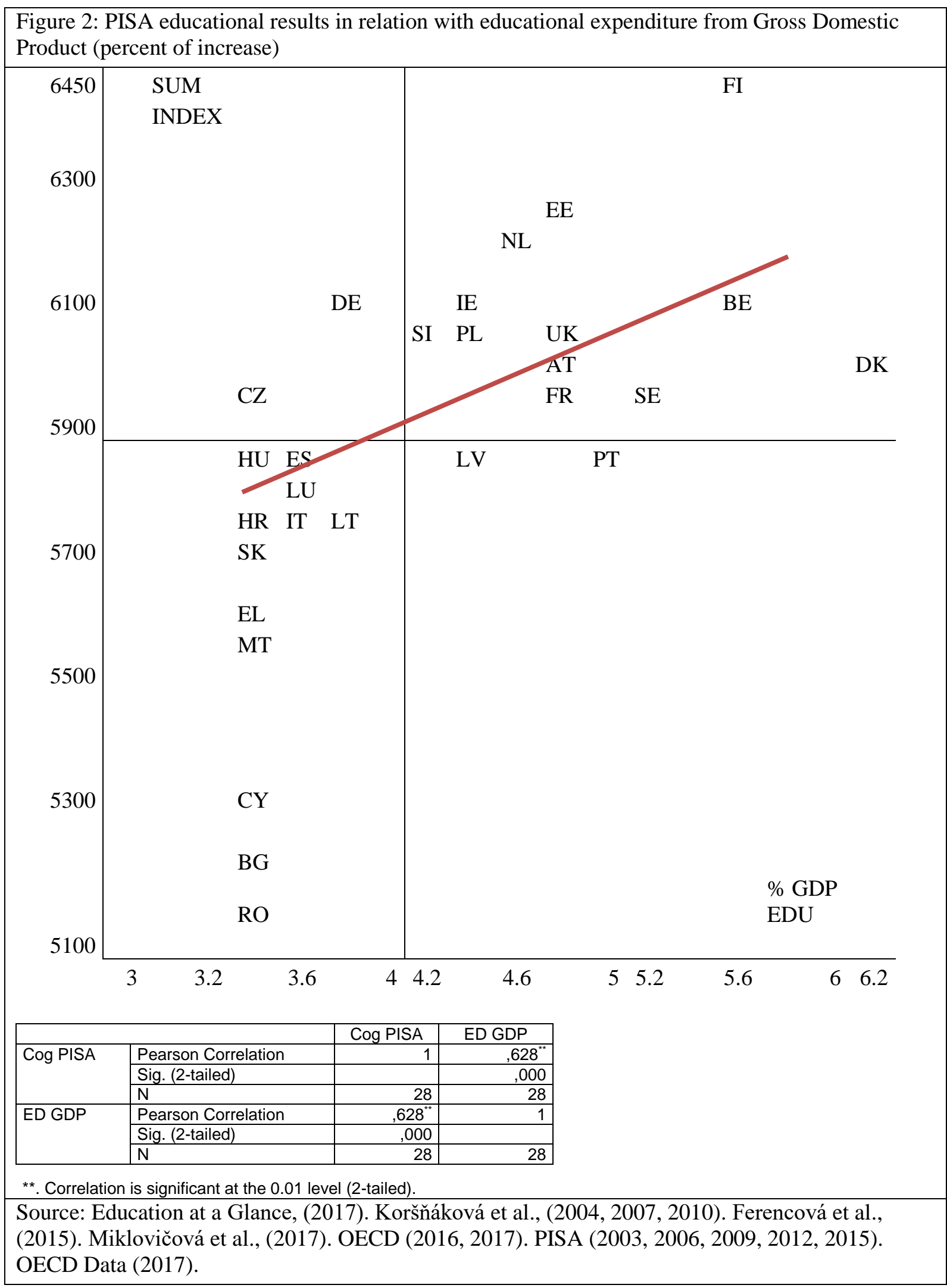

It can at the same time be stated that all of these Member States below the average value of the summary index, and which are also below the average value of the index of the education expenditure percentage of the gross domestic product, save for Latvia and Portugal, are in the left lower quadrant 
of the graph. In regard to the Member States such as Cyprus, Bulgaria and Romania, a below-average value of the summary index and a below-average value of the index of the education expenditure percentage of the gross domestic product are registered.

This graph shows an interesting oblique line inserted in the ranking of the Member States. From this display of the inserted oblique line, it is possible to infer a very significant relation between the summary index and index of the education expenditure percentage of the gross domestic product. Based on the graphical presentation, we deduce the assumption that with a growing education expenditure percentage of the gross domestic product (growing education expenditure), the summary index value increases. The increase in the value of the presumption of the positive impact of higher education expenditure is also indicated by the almost empty right lower quadrant in the graph, where only two Member States appear, however, on the average of the summary index value only. Similar results exist in the case of the analysis relating to particular surveys of the pupils' scientific, mathematical as well as reading literacy.

The results of the graphical presentation show that the above-average education expenditure percentage of the gross domestic product also affects, the above-average values of the index of the sum of the scores obtained in the pupils' scientific, mathematical and reading literacy for the sum of the years of 2006, 2009, 2012 and 2015 in the period under review. The right upper quadrant of the graph shows mostly states having, on a long-term basis, above-average and relatively stable results in the pupils' scientific, mathematical and reading literacy.

\section{Conclusions for the Most Important Findings}

The results indicate that the amount of the gross domestic product increment in particular Member States (the "economy growth") does not have to be decisive in affecting the quality of education. but these are other measures, probably mainly state priorities in the area of school policy of particular EU Member States.

It becomes evident that the above-average education expenditure percentage of the gross domestic product also affects the above-average values of the index of the sum of the scores obtained in the pupils' scientific, mathematical and reading literacy for the sum of the years 2006, 2009, 2012 and 2015 in the period under review. Member States which spend a higher above-average education expenditure percentage of their gross domestic product have, on a long-term basis, above-average and relatively stable results in the summary index but also individually - in the pupils' scientific, mathematical and reading literacy.

Decisions to increase education expenditure evidently positively affect the quality of education at schools, regardless of how the "economy is doing". Results of the analysis support the assumption that even in the case of a state's restrictive budget, expenditure on education and creative activity in general should not be restricted (Plavčan, 2018).

Deliberate creation, development, use and exploitation of knowledge the intellectual capital of employees is crucial for all organizations, both to ensure their further development and to gain and maintain a competitive advantage. In recent years, a significant increase in the importance of intellectual capital and its promotion as the most important form of capital has been observed (Šebestová, 2010).

\section{Abbreviations}

Finland FI, Estonia EE, the Netherlands NL, Germany DE, Belgium BE, Ireland IE, Poland PL, Slovenia SI, the United Kingdom UK, Denmark DK, Austria AT, France FR, the Czech Republic CZ, Sweden SE, Latvia LV, Hungary HU, Portugal PT, Spain ES, Luxembourg LU, Italy IT, Lithuania LT, Croatia HR, Slovakia SK, Greece EL, Malta MT, Cyprus CY, Bulgaria BG, Romania RO.

\section{References}

Education at a Glance (2017). OECD: OECD Data, Tab. B2.3.

Hanushek, E. A. (2016). Will More Higher Education Improve Economic Growth?: Oxford Review of Economic Policy, 32 (4), 538-552.

Koršňáková, P. (national coordinator). (2004). 2003 PISA Národná správa. [2003 PISA National Report.]: Štátny pedagogický ústav, Bratislava.

Koršňáková, P., Kováčová, J. (compilers). (2007). 2006 PISA Národná správa. [2006 PISA National Report.]: Štátny pedagogický ústav, Bratislava. 
Koršňáková, P., Kováčová, J., Heldová, D. (2010). 2009 PISA Národná správa. [2009 PISA National Report.]: Národný ústav certifikovaných meraní, Bratislava.

Ferencová, J., Stovíčková, J., Galádová, A. (compilers). (2015). 2012 PISA Národná správa. [2012 PISA National Report.]: Národný ústav certifikovaných meraní, Bratislava.

Miklovičová, J., Galádová, A., Valovič, J., Gondžúrová, K., (compilers). (2017). 2015 PISA Národná správa. [2015 PISA National Report.]: Národný ústav certifikovaných meraní, Bratislava.

OECD (2016). PISA 2015 Results in Focus: dx.doi.org.

OECD (2017). Education at a Glance: OECD Indicators. Paris.

PISA (2003, 2006, 2009, 2012, 2015). OECD: dx.doi.org.

OECD Data (2017). Real GDP Forecast 2012 - 2018. Total Annual Growth Rate (\%): OECD, Paris.

Plavčan, P. (2018). PISA. Cesta ku kvalite. [PISA. The Way to Quality.]: MSD, Brno, ISBN 878-80-7392-302-0.

Šebestová, P. (2010). Základy celostného manažmentu sociálnej práce. [The Basics of Holistic Management of Social Work]: Vysoká škola v Sládkovičove. ISBN 978-80-89267-41-5. 